\title{
Hvordan fandt brygger Jacob- sen frem til A. D. Jørgensen?
}

\section{Af Lorenz Rerup}

I en meget kyndig og veloplagt afhandling i Sønderjyske Årbøger 1982 (s. 163-193) har dr.phil. Harald Jørgensen behandlet tilblivelsen af sin farfar, A. D. Jørgensens berømte værk Fyrretyve Fortællinger af Fædrelandets Historie, som just da var udkommet for 100 år siden. Som bekendt blev 10.000 eksemplarer af værket dengang uddelt gratis i Nordslesvig, takket være et betydeligt tilskud fra brygger J. C. Jacobsen, Carlsberg, og dr. Jørgensen rejser $i$ sin redegørelse for denne gave og dens baggrund det spørgsmål (s. 182), hvorledes brygger Jacobsen fandt frem til A. D. Jørgensen? Spørgsmålet besvares med forskellige muligheder, bl.a. peges på tømrermester H. H. Kayser og på dr. Mathias Steenstrup, der var sekretær i Udvalget for Folkeoplysningens Fremme, som kom til at stå for udgivelsen af Fortællingerne. Dette svarer stort set til den formodning, som Troels G. Jørgensen fremsatte i bogen A. D. Jørgensen og 1864 (1964, s. 194) med henvisning til dels udgaven af faderens breve (1939, nr. 84), dels A. D. Jørgensens dagbog (i Danske Magazin, 7. række, 5. bd., 1949, s. 42).

Spørgsmålet kan imidlertid besvares helt klart. I min bog om A. D. Jørgensen (1965, s. 71) henviser jeg til den kendte nationalliberale politiker A. F. Krieger som mellemmand. Den unge A. D. Jørgensen havde gennem mange år nær personlig og faglig kontakt med Krieger, som 1880 var blandt dem "som gjorde brygger Jacobsen opmærksom på ham som den rette mand til at skrive en folkelig Danmarkshistorie for Nordslesvig«. Min bog er desværre ikke annoteret, men bygger på dette sted på en bemærkning hos den grundlærde historiograf Ellen Jørgensen, der i værket Historiens Studium i Danmark i det 19. Aarhundrede (1943, s. 207) henviser til personalhistorikeren Helga Stemann, f. Meldahl og hendes hovedværk »F. Meldahl og hans Venner«, bd. I-VI, 1926-32, (jvf. Ingrid Nielsen i Sdrj. Månedsskrift 1983 s. 80-85). Meldahl var en af datidens store danske arkitekter og arbejdede bl.a. sammen med J. C. Jacobsen om genopbygningen af Frederiksborg slot efter branden i 1859. Bryggeren gav meget væsentlige bidrag til restaureringen af slottet på betingelse af, at det blev 
omdannet til et nationalhistorisk museum. Meldahl og Krieger var venner.

Helga Stemann beretter (bd. V, 1931, s. 118 f.), at Jacobsen og Meldahl ofte talte om betydningen af, at folket gennem skrift, tale og billedlig fremstilling vaktes til interesse for landets historie, og at Jacobsen så det som en særlig national opgave at få udgivet en let læselig, kort fremstilling af den danske historie, som for en billig pris kunne gøres tilgængelig for hele den store befolkning. Denne tanke førte til, at Jacobsen spurgte Meldahl, hvem der mon var i stand til at skrive en sådan historie og også havde tid og lyst. Meldahl nævnte da straks A. D. Jørgensen, som på den tid var fuldmægtig i kongerigets arkiv og sekretær ved indenrigsministeriets kommission ang. en række offentlige bygninger, en kommission, Krieger var formand for, og Meldahl var medlem af (jf. også A. D. Jørgensens bibliografi i hans Historiske Afhandlinger, bd. IV, 1899, under året 1883). Jacobsen svarede, at han selv havde tænkt på Jørgensen, og at det fra flere sider var blevet sagt, at Jørgensens varme patriotiske følelse ville give sikkerhed for, "at det, jeg vil opnaa, det skeer, ifald han nu blot vil overtage Arbejdet.«

$\mathrm{Nu}$ er historikerne i reglen ikke trygge ved beretninger, der ligefrem indeholder replikskifter i direkte tale. Men Helga Stemann aftrykker også et brev, og det afgør sagen. Den i brevet nævnte captain Jacobsen er bryggeren, som var kaptajn i borgervæbningen. Brevet er dateret den 27. april 1881:

Kjære Etatsraad Meldahl!

Hvis De har Leilighed dertil, saa see at faa Captain Jacobsen til at henvende sig til Jørgensen jo før jo heller. Han er den Eneste mulige, og Tidspunktet er for Øieblikket heldigt, tilfældigvis ved jeg nemlig, at han endnu ikke har taget fat paa noget bestemt nyt Arbeide, men dette kunde let ske, hvis der ikke snart tales til ham om Sagen. Han er meget beskeden, saa det var Synd, hvis Jacobsen ikke tilbød ham et rigeligt Honorar.

Deres hengivne Fr. Krieger

Og på et brev, Krieger sendte Meldahl onsdag, den 3. maj 1881, har modtageren noteret: "Jeg fik det ordnet Fredag Aften med Jacobsen (Meldahl, bd. V, s. 192, note til s. 119). Heraf fremgår med al mulig tydelighed, at det var A. F. Krieger, der hjalp brygger Jacobsen med at 
finde frem til A. D. Jørgensen, og at han brugte F. Meldahl, der også kendte den unge historiker, og som må have talt med Krieger om sagen, som talerør. Og ikke kun den unge sønderjyde, også den gamle nationalliberale politiker var en beskeden mand. Han har næppe ønsket, at Jørgensen af den grund skulle komme til at stå i taknemmelighedsgæld til ham. Jørgensen fik derfor heller aldrig at vide, hvem der gav Jacobsen denne gode ide. 
